\title{
An Evaluation of Arizona Cooperative Extension's Rangeland Monitoring Program
}

\author{
Maria E. Fernandez-Gimenez, ${ }^{1}$ George Ruyle, ${ }^{2}$ and \\ Susan Jorstad McClaran ${ }^{3}$
}

\begin{abstract}
Authors are ${ }^{1}$ Assistant Professor, Department of Forest, Rangeland, and Watershed Stewardship, Colorado State University, Fort Collins, CO 80523-1472, and ${ }^{2}$ Professor and ${ }^{3}$ Senior Research Specialist, School of Renewable Natural Resources, 325 Biosciences East, University of Arizona, Tucson, AZ 85721.
\end{abstract}

\begin{abstract}
We evaluated Arizona Cooperative Extension's Rangeland Monitoring Program with the use of focus groups and a selfadministered mail survey of grazing permittees and natural resource agency employees. Our primary objectives were to 1) determine whether Extension is reaching its target audience, 2) describe the monitoring practices and attitudes of permittees and agency staff, 3) determine whether there is a relationship between permittees' exposure to Cooperative Extension and their monitoring and management practices, and 4) identify the monitoring information needs and preferences of permittees and natural resource agency staff. We found that Arizona's rangeland monitoring Extension program has been effective in reaching a large part of its target audience, and a significant proportion of Arizona permittees monitor on public, private, and stateowned rangelands. However, overall monitoring adoption rates remain low. Extension contact is associated with use of monitoring and other beneficial management practices, and permittees and agency employees report that monitoring increased their knowledge and led to changes in management. Monitoring by permittees improves agency-permittee relationships in many cases. Most permittees and agency employees believe that their respective peers are the most reliable source of monitoring information and prefer to receive information from Extension through face-to-face contact at workshops or personalized on-site assistance. The evaluation revealed important social dimensions of rangeland monitoring. Extension agents play a key role in facilitating the social process of monitoring, as well as providing technical training in monitoring skills. Further study is needed to investigate whether permittee monitoring actually leads to better management, improved economic returns, or increased tenure security.
\end{abstract}

\section{Resumen}

Utilizando grupos de enfoque y una autoevaluaciones por correo para los poseedores de permiso de pastoreo y los empleados de la agencia de recursos naturales, evaluamos el Programa de Monitoreo de Pastizales de la Extensión Cooperativa de Arizona. Nuestros objetivos primarios fueron: 1) determinar si la Extensión se está dirigiendo hacia el público de interés, 2) describir las prácticas de monitoreo y las actitudes por parte del los poseedores de permisos y los empleados de la agencia, 3) determinar si existe una relación entre las prácticas de manejo y de monitoreo de los poseedores de permiso y el ser expuestos a la Extension Cooperativa e 4) Identificar las preferencias y necesidades de información de monitoreo de parte los poseedores de permiso y los empleados de la agencia de recursos naturales. Encontramos que el Programa de Monitoreo de Pastizales de la Extensión de Arizona ha sido efectivo en dirigirse hacia gran parte de la población de interés y una proporción significativa de los poseedores de permiso de Arizona monitorea los pastizales públicos, privados y del Estado. Sin embargo las tarifas de adopción de monitoreo en general, permanecen bajas. El contacto de la Extensión está asociado con el uso de monitoreo y otras prácticas de manejo beneficiosas. Los poseedores de permisos y empleados de la agencia han reportado que el monitoreo incrementó su conocimiento y llevó a cambios de manejo. En muchos casos, el monitoreo por parte de los poseedores de permiso mejora la relación entre la agencia y los poseedores de permiso. La mayoria de poseedores de permiso y empleados de la agencia creen que sus compañeros respectivos son la fuente más confiable de informacion de monitoreo y prefirien recibir información de la Extensión a travéz del contacto persona a persona a base de talleres o con asistencia personalizada en el lugar de hecho. La evaluación reveló importantes dimensiones del monitoreo de pastizales. Los agentes de la Extension juegan un papel clave para facilitar el proceso social de monitoreo, asi como también proveen entrenamiento técnico en habilidades de monitoreo. Estudios a futuro son necesarios para investigar si el monitoreo por parte de los poseedores de permiso conlleva a un mejor manejo, a una mejora del ingreso económico o un incremento en la seguridad de arrendamiento.

Key Words: survey, permittee-agency relations, Cooperative Extension, focus group

Funding for this study was provided by University of Arizona Cooperative Extension and the Arizona Agricultural Experiment Station.

Correspondence: Maria E. Fernandez-Gimenez, Dept of Forest, Rangeland, and Watershed Stewardship, Colorado State University, Fort Collins, C0 80523-1472. Email: gimenez@cnr.colostate.edu

Manuscript received 10 November 2003; manuscript accepted 6 June 2004.

\section{INTRODUCTION}

Rangeland monitoring is thought to be a key component of good management because it enables managers to determine whether progress toward management objectives is being made and alerts them to trends that could threaten the sustainability 


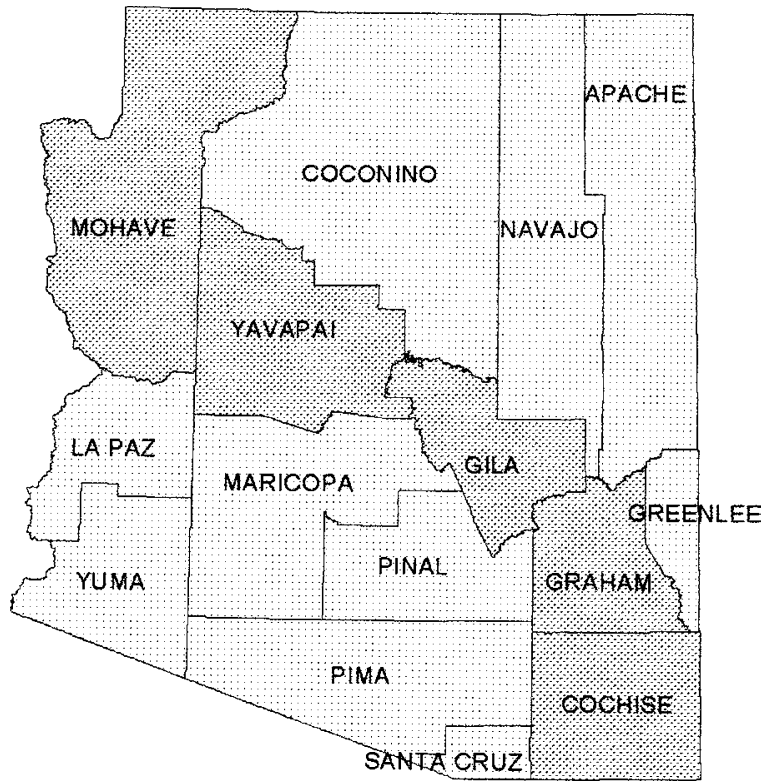

Figure 1. Map of study counties. Focus groups were conducted with ranchers and natural resource agency employees in each of the 5 study counties. A mail survey was sent to all US Forest Service, Bureau of Land Management, and Arizona State Land Department permittees in the 5 shaded counties.

of the rangeland ecosystem. Despite the apparent importance of monitoring to good stewardship, the scant data available suggest that only a small proportion of ranchers do any type of formal rangeland monitoring, and efforts to encourage monitoring by ranchers have not had much success (Richards and Huntsinger 1994; Richards and George 1996; Coppock and Birkenfeld 1999). At the same time, public land management agencies are increasingly scrutinized for their management practices and must monitor to meet environmental assessment and planning requirements and to comply with court judgments. Some agencies are turning to grazing permittees to help meet these monitoring obligations (Peterson 2000; F. Hayes, personal communication).

The University of Arizona Cooperative Extension Service has been providing training and assistance in rangeland monitoring to ranchers and natural resource agency staff since the 1970s and further formalized a rangeland monitoring Extension program in the 1990s. In 2001-2002, we undertook an evaluation of this program, 1) to determine whether the Extension program was reaching its target audiences, 2) to describe monitoring practices of permittees and agency staff, 3) to determine whether contact with the Extension Cooperative influenced rancher adoption of monitoring, and 4) to identify the monitoring information needs and preferences of current and potential Extension clientele. The evaluation, which focused on 5 Arizona counties, used a combination of qualitative (focus group) and quantitative (mail survey) methods to identify the program's effects, strengths, and weaknesses and to assess the association between Cooperative Extension contact and the monitoring practices and attitudes of Arizona permittees and natural resource agency staff.
Table 1. Percentage of permittee respondents with and without Extension contact who reported conducting different types of monitoring. Chi-square results refer to the difference in the proportion of permittees with and without Extension contact who reported using each monitoring practice.

\begin{tabular}{|c|c|c|c|c|c|}
\hline \multirow[b]{2}{*}{$\begin{array}{l}\text { Monitoring } \\
\text { method }\end{array}$} & \multicolumn{2}{|c|}{$\begin{array}{c}\text { Permittees with } \\
\text { Extension contact }(\%) \\
\end{array}$} & \multirow[b]{2}{*}{$\chi^{2}$} & \multirow[b]{2}{*}{$P$} & \multirow{2}{*}{$\begin{array}{l}\text { All } \\
\text { permittee } \\
\text { respondents } \\
\text { who use } \\
\text { method }(\%) \\
(n=311)\end{array}$} \\
\hline & $\begin{array}{l}\text { Who use } \\
\text { method } \\
(n=122)\end{array}$ & $\begin{array}{l}\text { Who do } \\
\text { not use } \\
\text { method } \\
(n=172)\end{array}$ & & & \\
\hline Any formal monitoring & 89 & 72 & 11.580 & 0.001 & 79 \\
\hline Measure rainfall & 84 & 66 & 12.159 & 0.000 & 73 \\
\hline Photo points & 53 & 20 & 32.950 & 0.000 & 33 \\
\hline Grazing exclosures & 39 & 26 & 5.595 & 0.018 & 31 \\
\hline Vegetation measurements & 39 & 23 & 7.986 & 0.005 & 31 \\
\hline Pace frequency & 25 & 6 & 19.689 & 0.000 & 14 \\
\hline Dry weight rank & 18 & 5 & 13.949 & 0.000 & 10 \\
\hline Comparative yield & 9 & 6 & 1.104 & 0.293 & 7 \\
\hline Clip biomass & 16 & 5 & 11.421 & 0.001 & 9 \\
\hline Parker 3-step & 14 & 1 & 19.259 & 0.000 & 6 \\
\hline $\begin{array}{l}\text { Ocular estimates } \\
\text { of cover }\end{array}$ & 25 & 11 & 11.478 & 0.001 & 16 \\
\hline $\begin{array}{l}\text { Transect estimates } \\
\text { of cover }\end{array}$ & 37 & 15 & 19.654 & 0.000 & 24 \\
\hline Herbaceous utilization & 32 & 11 & 21.114 & 0.000 & 18 \\
\hline Browse utilization & 38 & 20 & 11.595 & 0.001 & 27 \\
\hline Riparian utilization & 36 & 12 & 23.588 & 0.000 & 22 \\
\hline $\begin{array}{l}\text { Riparian vegetation } \\
\text { density }\end{array}$ & 29 & 11 & 14.816 & 0.000 & 19 \\
\hline Stream bank stability & 20 & 15 & 1.356 & 0.244 & 17 \\
\hline Water quality & 22 & 17 & 1.004 & 0.316 & 21 \\
\hline Wildlife habitat surveys & 21 & 15 & 2.286 & 0.131 & 18 \\
\hline Wildlife counts & 25 & 11 & 10.424 & 0.001 & 17 \\
\hline
\end{tabular}

\section{METHODS}

\section{Sampling Frames}

Two populations were sampled; federal grazing permittees and state land lessees (hereafter "permittees") and land management agency employees. Five of Arizona's 15 counties were chosen for study on the basis of the involvement of county Extension agents in the rangeland monitoring program and the desire to obtain information from diverse geographic regions within the state. The 5 study counties were: Cochise, Gila, Graham, Mohave, and Yavapai (Fig. 1). For sampling purposes, Cochise and Graham counties were treated as 1 unit because they share the same Extension agent and local Cattlegrowers Association; Mohave County was divided into 2 units, Kingman and the Arizona Strip, because permittees north and south of the Grand Canyon are served by different Bureau of Land Management (BLM) and US Forest Service (USFS) units.

Land management agency staff included employees of the USFS, BLM, Natural Resources Conservation Service (NRCS), and Arizona State Land Department (ASLD). To be included in the survey, an agency employee must have conducted or supervised rangeland monitoring or used monitoring data to make management decisions or recommendations. Lists of 
agency employees who met at least one of these criteria were obtained from agency contacts and directories. Agency employees included rangeland management specialists and conservationists, other resource specialists (e.g. wildlife biologists, ecologists, soil scientists, and hydrologists), National Environmental Policy Act (NEPA) and interdisciplinary team members, range program supervisors, and line officers.

The names and addresses of all USFS and BLM grazing permittees and ASLD grazing lessees in each of the 5 study counties were obtained from the agencies. The survey specified that the respondent must have grazed livestock in 1 of the 5 study counties in the past 10 years.

\section{Surveys}

A self-administered mail survey was implemented July-September 2002. The objective of this survey was to obtain quantitative data on the monitoring knowledge, attitudes, and practices of permittees and land management agency employees, as well as their experiences with Cooperative Extension and their monitoring information needs and preferences. The survey questions were developed on the basis of the evaluation objectives, focus group results, and design of past rancher and agency surveys (Richards and Huntsinger 1994; Brunson and Steel 1996; Coppock and Birkenfeld 1999; Liffman et al. 2000). Survey drafts were reviewed and pretested by 4 ranchers, 3 agency employees, extension agents, and several experienced researchers and were revised numerous times before the final version was completed. Care was taken to be sure that the meaning of "rangeland monitoring" was clear to all respondents by differentiating between informal and formal monitoring and asking about the specific monitoring methods used (see Table 1). The survey consisted of 5 sections: Monitoring Practices, Information Needs and Preferences, Management Practices, Beliefs and Attitudes about Rangelands and Rangeland Management, and Ranching Operation and Background. Slightly different versions of the survey were sent to permittees and agency staff. The permittee survey included 37 questions and the agency survey 32 questions.

The survey was sent to all USFS, BLM, and ASLD grazing permittees and lessees in the 5 study counties and all USFS, BLM, ASLD, and NRCS employees in Arizona fitting the previously mentioned criteria. A universal sample (census) was taken rather than a random sample to ensure sufficient response for analysis because fewer than 700 permittees graze in all 5 counties and we conservatively planned on a $30 \%$ response rate. Similarly, the total number of agency employees in Arizona meeting our criteria was 177. Because there are many more USFS than BLM, NRCS, or ASLD employees meeting our criteria for inclusion in the sample frame, the USFS was disproportionately represented in our sample.

In accordance with the total design method for survey implementation (Dillman 2000), the survey mailing was preceded by an introductory letter and followed by a reminder postcard. Replacement surveys were sent to those who did not respond to the first survey after 4 weeks. Forty-seven percent of permittees $(n=311)$ and $73 \%$ of agency employees $(n=129)$ responded to the survey.

Several factors might have inhibited some permittees from responding. The survey might have lacked salience for permittees who do not monitor or have no experience with Co- operative Extension. Also, the survey was fairly long and the severe drought and resulting stress on ranching operations in Arizona during the summer of 2002 could have influenced some permittees not to respond. Because permittees who returned their surveys might differ in important ways from those who did not respond, we conducted a follow-up telephone survey of 30 randomly selected nonrespondents. Nonrespondents did not differ from respondents in their exposure to Extension, their rating of Extension services, their attitudes toward monitoring on public lands, the scale of their ranching operation (in deeded acres or head of cattle), the percentage of their annual income derived from livestock, the county where they reside, or the type of grazing privileges they possess (USFS, BLM, or ASLD). Nonrespondents were, however, older, less educated, and less likely to do formal monitoring than were respondents. They were more likely to use several beneficial management practices, such as installing water pipelines, wildlife-friendly fencing, and wildlife waters, and using herbicides to treat noxious weeds, but less likely to implement prescribed burns. These results suggest that caution should be exercised in generalizing from our results with respect to some of the variables discussed in this article. For example, our survey might overestimate the proportion of permittees who do formal monitoring. Nevertheless, the survey provides an accurate description of the views and characteristics of more than 300 Arizona permittees who are similar in many ways to the larger population they are intended to represent.

\section{Survey Analyses}

Survey responses were numerically coded and entered into an Excel spreadsheet by a professional data entry firm. Because many respondents left 1 or more questions blank, the response rate for individual questions varied. All usable surveys were included in the analyses despite missing questions. All data analyses were performed with SPSS version 10.0 for Windows (SPSS 1999).

Variables used in analysis of the survey data were categorical, ordinal, continuous or scale-level, and open-ended qualitative responses. The descriptive objectives of the study were met by tabulating frequencies. These included the type of monitoring conducted by permittees and agencies, their use of different information sources, and each group's preference for information types and content. The hypothesis that permittees with Extension contact differ from other permittees with respect to the types of monitoring and management practices they use was assessed with contingency tables, with chi-square measures of nominal association (Norusis 1990). Student's $t$ tests were used to assess differences in the mean number of management and monitoring practices used by permittees, with and without Extension contact, and the mean number of management practices used by permittees who do and do not monitor. Differences were considered significant at $P<0.10$.

\section{Focus Groups}

A focus group is a facilitated discussion of several themes related to a main topic (Stewart and Shamdasani 1998). Focus groups are a useful tool for inductive and exploratory research geared to asking questions about "what kind?" "why?" and "how?" rather than "how many?" "how much?" and "how 
Table 2. Importance of various reasons for monitoring to permittees and natural resource agency employees in response to the question: How important to you is each of the following reasons for monitoring? ${ }^{1}$

\begin{tabular}{|c|c|c|c|}
\hline & & Permittees & Agency Employees \\
\hline $\begin{array}{l}\text { Reasons for } \\
\text { Monitoring }\end{array}$ & $n$ & $\begin{array}{cc} & \text { Not } \\
\text { Important } & \text { important } \\
(\%) & (\%)\end{array}$ & $\begin{array}{cc} & \text { Not } \\
\text { Important } & \text { important } \\
(\%) & (\%)\end{array}$ \\
\hline
\end{tabular}

Helps me (agency)

know if the

condition of the

range is improving

or not

$\begin{array}{llllll}254 & 98 & 1 & 113 & 100 & 0\end{array}$

Helps me (agency)

determine if

management

objectives are

being met

Helps me (agency)

decide when and

where to move

livestock

Helps me (agency)

decide when to

decrease or increase

herd size

Helps agency advise

rancher on livestock

management

Protects me (agency) against lawsuits

Increases my (agency)

credibility with agency

(ranchers)

Increases my (agency)

credibility with the

public

Increases overall value of my ranch

Helps me maintain or increase permitted

AUMs

Required by a

government

program

Required by a court decision

Required by law or agency policy

Helps me get government funds for range improvements

Protects my property rights

\begin{tabular}{|c|c|c|c|c|}
\hline 238 & 97 & 3 & 113 & 99 \\
\hline 251 & 88 & 13 & 110 & 94 \\
\hline \multirow[t]{2}{*}{252} & 88 & 12 & 109 & 88 \\
\hline & NA & NA & 112 & 93 \\
\hline 211 & 50 & 50 & 112 & 77 \\
\hline 236 & 80 & 21 & 109 & 84 \\
\hline 227 & 80 & 20 & 111 & 91 \\
\hline 239 & 81 & 20 & & NA \\
\hline 238 & 84 & 16 & & NA \\
\hline \multirow[t]{3}{*}{197} & 39 & 62 & & NA \\
\hline & NA & NA & 109 & 69 \\
\hline & NA & NA & 111 & 90 \\
\hline 209 & 41 & 59 & & NA \\
\hline 225 & 80 & 20 & & NA \\
\hline
\end{tabular}

${ }^{1}$ The survey included 4 possible responses: very important, somewhat important, not too important, and not at all important. Responses in the "very important" and "somewhat important" categories are combined in this table as are responses in the "not too important" and "not at all important" categories. Wording in parentheses reflects the agency version of the questionnaire.
Table 3. Importance of various obstacles to monitoring to permittees and natural resource agency employees in response to the question: How important is each of the following potential obstacles in determining how much formal range monitoring you do? ${ }^{1}$

\begin{tabular}{|c|c|c|c|c|c|c|}
\hline \multirow[b]{2}{*}{$\begin{array}{l}\text { Obstacles to } \\
\text { monitoring }\end{array}$} & \multirow[b]{2}{*}{$n$} & \multicolumn{2}{|c|}{ Permittees } & \multirow[b]{2}{*}{$n$} & \multicolumn{2}{|c|}{ Agency employees } \\
\hline & & $\begin{array}{l}\text { Important } \\
(\%)\end{array}$ & $\begin{array}{c}\text { Not } \\
\text { important } \\
(\%)\end{array}$ & & $\begin{array}{l}\text { Important } \\
(\%)\end{array}$ & $\begin{array}{c}\text { Not } \\
\text { important } \\
(\%)\end{array}$ \\
\hline Lack of time & 263 & 72 & 28 & 128 & 94 & 7 \\
\hline Lack of help & 250 & 70 & 30 & 127 & 56 & 44 \\
\hline Expense & 243 & 51 & 49 & 125 & 59 & 41 \\
\hline Paperwork & & NA & NA & 127 & 58 & 43 \\
\hline $\begin{array}{l}\text { Lack of knowledge } \\
\text { of monitoring }\end{array}$ & & & & & & \\
\hline methods & 253 & 69 & 31 & 127 & 31 & 69 \\
\hline Lack of confidence & & & & & & \\
\hline in monitoring skills & 254 & 51 & 49 & 126 & 27 & 73 \\
\hline $\begin{array}{c}\text { Tediousness of } \\
\text { monitoring }\end{array}$ & 242 & 45 & 56 & 126 & 33 & 66 \\
\hline $\begin{array}{l}\text { Complexity of } \\
\text { monitoring }\end{array}$ & 243 & 52 & 49 & 126 & 33 & 67 \\
\hline $\begin{array}{l}\text { Lack of confidence } \\
\text { in scientific validity } \\
\text { of monitoring }\end{array}$ & & & & & & \\
\hline $\begin{array}{l}\text { methods } \\
\text { Land management } \\
\text { agency won't } \\
\text { accept my }\end{array}$ & 247 & 53 & 46 & 126 & 31 & 69 \\
\hline $\begin{array}{l}\text { monitoring data } \\
\text { Lack of consistent } \\
\text { monitoring methods } \\
\text { between agencies }\end{array}$ & 224 & 37 & 63 & & NA & NA \\
\hline $\begin{array}{l}\text { or over time } \\
\text { Monitoring doesn't } \\
\text { help me make } \\
\text { management }\end{array}$ & 230 & 55 & 45 & 125 & 60 & 40 \\
\hline decisions & 231 & 30 & 60 & 122 & 28 & 72 \\
\hline $\begin{array}{l}\text { Monitoring is the } \\
\text { land management }\end{array}$ & & & & & & \\
\hline agency's responsibility & 228 & 27 & 73 & & NA & NA \\
\hline $\begin{array}{l}\text { Other agency priorities } \\
\text { preempt monitoring }\end{array}$ & & NA & NA & 125 & 77 & 22 \\
\hline $\begin{array}{l}\text { I'm afraid (concerned) } \\
\text { monitoring data } \\
\text { could be used against }\end{array}$ & & & & & & \\
\hline me (agency) & 245 & 39 & 62 & 126 & 13 & 87 \\
\hline
\end{tabular}

often?” In October 2001 to January 2002, we held focus groups with permittees and natural resource agency employees in each study county. These gatherings served 4 purposes. First, they allowed us to document individual experiences and concerns about monitoring and Cooperative Extension. Second, the focus groups enabled us to craft a relevant and effective survey by incorporating the language used and issues raised by the target populations during these discussions. For example, the 
lists of reasons why permittees and natural resource agency staff do and do not monitor (see Tables 2 and 3) were derived in large part from focus group comments. Third, the combined use of focus groups and a survey helped to validate our conclusions by enabling us to cross-check qualitative findings with quantitative results. Finally, focus groups are useful in eliciting information about and explaining phenomena or relationships that might be difficult to assess through a mail survey or which were beyond the scope of our quantitative evaluation.

Invitations to focus groups were issued to selected permittees and natural resource agency employees on the basis of referrals from county Extension agents and agencies. Focus group meetings were held in county Extension offices or public spaces such as the county library or museum. Two of the agency meetings took place in agency conference rooms. Focus group meetings were tape recorded and transcribed. Forty-six permittees and 40 natural resource agency employees participated in the 10 focus groups, each of which lasted 1 and one-half to 2 hours. Attendance at focus groups ranged from 3 to 17 participants, with an average of 8.5 participants.

Focus group data were analyzed by coding the transcribed focus group notes with qualitative data analysis software N*VIVO version 1.2 (QSR 2000). N*VIVO facilitates the process of identifying, organizing, and comparing themes that emerge from transcript or other text data. We used a descriptive and inductive approach to analyzing the focus group data, approaching the transcripts without any a priori hypotheses about what we would find. This method of analysis, known as grounded theory, seeks to develop theory specific to the object of investigation (in this case, Cooperative Extension's involvement in rangeland monitoring) that is "grounded" in qualitative, empirical data (Strauss and Corbin 1998). Data that do not fit with the themes are considered in relationship to alternative hypotheses, and theory is developed through the iterative process of comparing and rechecking emerging hypotheses against the data. Although the main emphasis of this paper is the survey, several key evaluation findings that were not addressed in the survey emerged from the focus groups. We report these findings alongside the survey results in the relevant sections below.

\section{RESULTS}

\section{Respondent Characteristics}

The majority of permittee respondents operate cow-calf $(76 \%)$ or cow-calf and yearling (19\%) ranching operations. The average ranch includes $24 \%$ private land, $23 \%$ USFS, $25 \%$ BLM, and $27 \%$ ASLD lands. Half of the permittees own more than 1000 acres of deeded land and $27 \%$ own $<250$ deeded acres. The mean cattle herd size as of 1 May 2002 was 223 (range 1-3 500). Note that herds might have been smaller than usual because of drought destocking. For the majority of permittees $(80 \%)$, at least half of the yearly labor is supplied by family members, and on average, $81 \%$ of labor is from family. Permittee respondents have managed their current ranches for 23 years (range 1-77 years) and are 59 years old on average. Forty-four percent of permittees have completed at least a 4 -year college degree $(18 \%$ have a graduate or professional degree), and only $4 \%$ have $<12$ years of formal schooling. The average permittee respondent derives $43 \%$ of his or her income from livestock, $47 \%$ from off-ranch sources, $2 \%$ from crops, and $<1 \%$ from wildlife. For the 13 permittees reporting crop income and the 3 with wildlife revenues, however, these sources make significant contributions (36\% and $26 \%$, respectively) to annual income. Only $63 \%$ of the permittee respondents reported their approximate gross annual income. For these permittees, the mean annual income is $\$ 107600$ (range $\$ 5000-\$ 1000000$ ). One outlier, who reported an annual income of $\$ 10000000$, was dropped from this analysis.

The average agency respondent is 47 years old, has worked for her or his current employer for 18 years, and has been a natural resource professional for 20 years. Ninety-six percent of agency respondents have a 4 -year college degree and 34\% have a graduate degree. Sixty percent of agency respondents have an undergraduate degree in range management, $11 \%$ in wildlife management, $9 \%$ each in biological sciences and forestry, $5 \%$ in soils, and $3 \%$ in business or economics. Of those agency respondents with a graduate degree, $42 \%$ have degrees in range management; $21 \%$ in wildlife management; $14 \%$ in forestry; $12 \%$ in biological sciences; $5 \%$ in social science, education, or humanities; and $2 \%$ each in hydrology and agriculture. Ninety-one percent of agency respondents participate in at least some field monitoring.

\section{Extension Effectiveness}

Effect on Target Audience. Extension's rangeland monitoring program has reached a greater proportion of its agency audience than its permittee audience, but the effect of the program has been similar for individuals of both groups who received Cooperative Extension monitoring services. Seventy percent of agency respondents and $42 \%$ of permittees reported receiving range monitoring information or services from $\mathrm{Co}^{-}$ operative Extension. Of those who received information or services, $86 \%$ of permittees and $85 \%$ of agency employees said that the information increased their knowledge or understanding of range monitoring somewhat or a lot. Fifty-nine percent of permittees and $64 \%$ of agency employees said that the information they received from Extension affected their monitoring or management activities. In response to an open-ended question that asked for elaboration on how they were affected, the majority of both groups specified that their monitoring methods or use of monitoring was improved, along with other positive effects.

Monitoring Adoption and Obstacles to Monitoring. Seventynine percent of permittees reported doing some type of formal monitoring (Table 1). Of these, 94\% measure rainfall, $43 \%$ use photo points, $40 \%$ use grazing exclosures, and 39\% collect some type of quantitative vegetation measurements. Permittees who have had exposure to Cooperative Extension's rangeland monitoring program are more likely to conduct most types of formal monitoring. For example, $53 \%$ of permittees with Extension exposure use photo points, whereas only $20 \%$ of permittees without Extension exposure use them. Although the proportion of permittee respondents who use any given formal vegetation monitoring practice remains fairly low (ranging from 6 to $24 \%$ for various methods), 2 to 4 times more permittees with Extension exposure use each method except comparative yield. Extension clients also used significantly more monitoring 
Table 4. Percentage of permittee respondents with and without Extension contact who reported conducting specified management practices in the past 10 years. Chi-square results refer to the difference in the proportion of permittees with and without Extension contact who reported using each monitoring practice.

\begin{tabular}{|c|c|c|c|c|c|}
\hline \multirow[b]{2}{*}{ Monitoring practice } & \multicolumn{2}{|c|}{$\begin{array}{c}\text { Permittees with } \\
\text { Extension contact }(\%)\end{array}$} & \multirow[b]{2}{*}{$\chi^{2}$} & \multirow[b]{2}{*}{$P$} & \multirow[b]{2}{*}{$\begin{array}{c}\text { All } \\
\text { permittees } \\
\text { who use } \\
\text { practice }(\%) \\
(n=311)\end{array}$} \\
\hline & $\begin{array}{c}\text { Who use } \\
\text { practice } \\
(n=122)\end{array}$ & $\begin{array}{l}\text { Who do } \\
\text { not use } \\
\text { practice } \\
(n=172)\end{array}$ & & & \\
\hline Rotational grazing & 43 & 57 & 2.023 & 0.155 & 87 \\
\hline \multicolumn{6}{|l|}{$\begin{array}{l}\text { Holistic resource } \\
\text { management or }\end{array}$} \\
\hline Savory grazing & 21 & 10 & 6.556 & 0.010 & 14 \\
\hline Drought destocking & 85 & 77 & 3.258 & 0.071 & 79 \\
\hline Laid water pipelines & 68 & 58 & 3.321 & 0.068 & 61 \\
\hline \multicolumn{6}{|l|}{ Seasonal grazing of } \\
\hline \multicolumn{6}{|l|}{ Fenced stream banks } \\
\hline or riparian areas & 23 & 8 & 14.092 & 0.000 & 14 \\
\hline $\begin{array}{l}\text { Nonuse (other } \\
\text { than drought) }\end{array}$ & 44 & 34 & 3.363 & 0.067 & 38 \\
\hline Prescribed burn & 25 & 15 & 4.155 & 0.042 & 19 \\
\hline Reseeding & 25 & 31 & 1.365 & 0.243 & 29 \\
\hline \multicolumn{6}{|l|}{ Wildlife-friendly } \\
\hline Herbicides & 12 & 11 & 0.075 & 0.784 & 11 \\
\hline \multicolumn{6}{|l|}{ Mechanical brush } \\
\hline removal & 32 & 24 & 2.382 & 0.123 & 28 \\
\hline Install wildlife waters & 42 & 27 & 6.732 & 0.009 & 33 \\
\hline $\begin{array}{l}\text { Erosion control } \\
\text { structures }\end{array}$ & 37 & 34 & 0.208 & 0.648 & 35 \\
\hline
\end{tabular}

methods $(6.7 \pm 4.5 \mathrm{SD})$ than permittees without Extension contact who monitor $(3.7 \pm 3.4 \mathrm{SD}$; Student's $t=6.26$, $\mathrm{df}=216, P<0.0001)$. Of the 80 permittees $(27 \%)$ who said they were not familiar with any of the practices, $>$ twothirds had no Extension contact.

The vast majority of permittees who monitor (91\%) reported that the ranch owner participates in monitoring. Seventeen percent of permittees reported that Cooperative Extension participated in monitoring on their ranches, whereas $66 \%$ of agency employees reported that Extension had participated in monitoring with the agency at least once.

Permittees and agency employees who monitor valued monitoring for the same reasons: to gauge whether the condition of the range is improving $(98 \%$ and $100 \%$, respectively) and to determine whether management objectives are being met (97\% and $99 \%$; Table 2). Other top reasons for monitoring shared by both groups related to making specific management decisions: when and where to move livestock $(88 \%$ and $94 \%)$ and when to increase or decrease herd size $(88 \%$ and $89 \%)$. The 5 th most important reason for permittees was to help increase or maintain the number of permitted animal unit months (AUMs) (84\%). Although court decisions did not rank as high in importance as the top reasons cited, this
Table 5. Effects of permittee monitoring on permittee-agency relationships as perceived by permittees and agency employees.

\begin{tabular}{|c|c|c|c|c|c|}
\hline \multirow[b]{2}{*}{ Permittees } & \multicolumn{5}{|c|}{ My relationship with the agency is (\%) } \\
\hline & $\begin{array}{l}\text { Greatly } \\
\text { improved }\end{array}$ & $\begin{array}{l}\text { Somewhat } \\
\text { improved }\end{array}$ & Unchanged & $\begin{array}{l}\text { Somewhat } \\
\text { worse }\end{array}$ & $\begin{array}{l}\text { Much } \\
\text { worse }\end{array}$ \\
\hline \multicolumn{6}{|c|}{ As a result of my monitoring on my ... } \\
\hline \multicolumn{6}{|l|}{$\begin{array}{l}\text { Forest Service } \\
\text { allotments }\end{array}$} \\
\hline$(n=142)$ & 13 & 26 & 49 & 8 & 4 \\
\hline \multicolumn{6}{|c|}{ Bureau of Land } \\
\hline \multicolumn{6}{|c|}{$\begin{array}{l}\text { Management } \\
\text { allotments }\end{array}$} \\
\hline$(n=126)$ & 21 & 24 & 54 & 2 & 0 \\
\hline \multicolumn{6}{|l|}{ State Land } \\
\hline \multicolumn{6}{|l|}{ leases } \\
\hline \multirow[t]{2}{*}{$(n=179)$} & 17 & 21 & 62 & 0 & 1 \\
\hline & \multicolumn{5}{|c|}{ The agency's relationship with the permittee is (\%) } \\
\hline $\begin{array}{l}\text { Agency } \\
\text { employees }\end{array}$ & $\begin{array}{l}\text { Greatly } \\
\text { improved }\end{array}$ & $\begin{array}{l}\text { Somewhat } \\
\text { improved }\end{array}$ & Unchanged & $\begin{array}{l}\text { Somewhat } \\
\text { worse }\end{array}$ & $\begin{array}{l}\text { Much } \\
\text { worse }\end{array}$ \\
\hline \multicolumn{6}{|c|}{ As a result of permittee or landowner. } \\
\hline \multicolumn{6}{|c|}{$\begin{array}{l}\text { Participation in } \\
\text { monitoring }\end{array}$} \\
\hline$(n=100)$ & 37 & 46 & 14 & 3 & 0 \\
\hline \multicolumn{6}{|l|}{$\begin{array}{l}\text { Monitoring on } \\
\text { their own }\end{array}$} \\
\hline$(n=81)$ & 30 & 43 & 21 & 6 & 0 \\
\hline
\end{tabular}

was still a very important reason to monitor for $42 \%$ of agency respondents, and protection against lawsuits was very important to $46 \%$ of them.

Protecting private property rights and increasing their credibility with the agency were very important reasons for monitoring for $56 \%$ of the responding permittees. Permittees who received monitoring information or services from Extension were more likely to perceive protection from lawsuits and increasing their credibility with agencies and with the public as important reasons for monitoring than permittees who had no Extension contact. This might reflect information they obtained from Extension, but it might also be because permittees with concerns about lawsuits and credibility are more likely to seek Extension assistance.

Interest in increasing monitoring was widespread among all respondents. Thirty-two percent of permittees and $71 \%$ of agency employees felt that they are not doing enough monitoring now. Both permittees and agency employees identified lack of time as the main obstacle to monitoring, but this was a problem for more agency staff $(94 \%)$ than permittees $(72 \%$; Table 3). Lack of help, lack of knowledge of monitoring methods, expense, and lack of confidence in the scientific validity of monitoring methods were the other top obstacles for permittees. Agency employees cited lack of help, expense, and paperwork as obstacles, but the most important constraint for agencies after lack of time was pre-emption of monitoring by other agency priorities. Few agency employees were deterred by the possibility that monitoring data might be used against them. Although the majority of permittees $(62 \%)$ also were not 
Table 6. Current sources of information on rangeland monitoring. Of those respondents who reported looking for information on rangeland monitoring ( $66 \%$ of permittees and $88 \%$ of agency employees), the percentage who sought information from the listed sources are reported.

\begin{tabular}{lcc}
\hline Information source & $\begin{array}{c}\text { Permittees }(\%) \\
(n=195)\end{array}$ & $\begin{array}{c}\text { Agency } \\
\text { employees }(\%) \\
(n=113)\end{array}$ \\
\hline NRCS/SCS range conservationist & 40 & 42 \\
Forest Service range conservationist & 25 & 23 \\
Bureau of Land Management range & & \\
$\quad$ conservationist & 21 & 11 \\
State Land Department range conservationist & 14 & 1 \\
Other federal agency range conservationist & 1 & 0 \\
Cooperative Extension range monitoring & & \\
$\quad$ workshop & 50 & 63 \\
Cooperative Extension monitoring publication & 40 & 64 \\
Cooperative Extension agent & 39 & 50 \\
Ranchers & 57 & 32 \\
Private range management consultant & 23 & 18 \\
University professor & 22 & 63 \\
World Wide Web & 14 & 39 \\
Textbook & 8 & 28 \\
Range management class in college & 24 & 55 \\
Holistic resource management workshop & 25 & 34 \\
Society for Range Management & 20 & 63 \\
Other (write-in response): Interagency & & 15 \\
$\quad$ technical references & $<1$ & \\
\hline
\end{tabular}

concerned about this, a substantial minority $(18 \%)$ said that fear that data might be used against them was a very important obstacle to monitoring, and 39\% found that it was at least a somewhat important obstacle. On the survey, one-third of permittees and nearly one-third of agency employees responded that monitoring did not help them make management decisions. Similarly, focus group participants expressed frustration that monitoring on allotments often was not tied to specific management objectives or desired future conditions. Permittees who participated in focus groups also commented that the time frame for obtaining monitoring results limited their utility for making management decisions.

Improved Stewardship. Stewardship was assessed by asking permittees which of 15 listed practices they have implemented on their ranches in the past 10 years (Table 4). Ninety-six percent of permittees reported using at least 1 of these management practices in the past 10 years on any part of their ranch (public, private, or state lands). The most common practices used were rotational grazing $(87 \%)$, drought destocking $(79 \%)$, pipeline $(61 \%)$ and spring development $(50 \%)$, nonuse other than for drought $(38 \%)$, seasonal grazing of riparian areas $(35 \%)$, and erosion control structures $(35 \%)$.

Contact with Extension is associated with increased use of beneficial management practices by permittees. Except for rotational grazing and reseeding, more permittees with Extension exposure implemented each of the listed management practices. Permittees who are Extension clients were significantly more likely to use the following practices than other permittees: holistic resource management (HRM) or Savory grazing, seasonal grazing of riparian areas, spring development,
Table 7. Permittee and agency preferences for information delivery. Of those who checked at least 1 item on the list, the percentage of respondents who find this information source helpful.

\begin{tabular}{lcc}
\hline Information source & $\begin{array}{c}\text { Permittees }(\%) \\
(n=287)\end{array}$ & $\begin{array}{c}\text { Agency } \\
\text { employees }(\%) \\
(n=122)\end{array}$ \\
\hline Pamphlet & 39 & 31 \\
Video & 31 & 22 \\
Newsletter & 27 & 16 \\
Demonstration & 41 & 50 \\
Workshop or class & 50 & 74 \\
Testimonial from ranchers & 18 & 6 \\
Computer CD-ROM & 11 & 17 \\
Internet Web site & 15 & 41 \\
Newspaper or magazine article & 10 & 5 \\
Television & 5 & 1 \\
Radio & $<1$ & 0 \\
On-site help from Extension & & \\
$\quad$ agent or other professional & 55 & 51 \\
Textbook & 11 & 12 \\
\hline
\end{tabular}

fencing of stream banks or riparian areas, prescribed burning, wildlife fencing, and wildlife waters. Extension clients implemented significantly more practices on average (6.52 \pm 2.54 $\mathrm{SD})$ than other permittees $(5.07 \pm 2.76 \mathrm{SD}$; Student's $t=4.58$, $\mathrm{df}=292, P<0.0001)$.

Participation in rangeland monitoring was also associated with increased use of beneficial management practices. Permittees who monitor were more likely to implement each of the listed management practices than those who do not. The relationship between monitoring and implementation of practices was statistically significant for 5 practices: rotational grazing, spring development, fencing stream banks or riparian areas, installing wildlife waters, and building erosion control structures. Permittees who monitor also implemented significantly more practices on average $(5.94 \pm 2.83 \mathrm{SD})$ than those who did not (4.39 \pm 2.41 SD; Student's $t=14.107, \mathrm{df}=309, P<0.0001)$.

Communication, Cooperation, and Trust. Although the majority of permittees reported in the survey that their relationships with agencies were unchanged as a result of monitoring (Table 5 ), a substantial minority reported that their relationships with agencies were somewhat or greatly improved $339 \%$ for USFS, $45 \%$ for BLM, $38 \%$ for ASLD). Twelve percent of permittees felt their relationship with the Forest Service was worse as a result of monitoring.

Agency staff perceived more dramatic positive effects of monitoring on their relationships with permittees. Eighty-three percent of agency respondents felt that their relationships with permittees were at least somewhat improved when permittees and agency staff monitor together, and $73 \%$ felt they were improved when permittees monitor on their own. Only $3 \%$ of agency employees felt that their relationships with permittees were worse as a result of monitoring together, and $6 \%$ said they were worse as a result of permittees monitoring on their own.

The focus groups highlighted the role that Cooperative Extension plays in fostering cooperation within and among agencies and among agencies, permittees, and, in some cases, other interest groups. In some instances, Extension plays a direct 
Table 8. Permittee and agency monitoring information needs. Of those who checked at least 1 item on the list, the percentage of respondents who need or would like to have information on this topic.

\begin{tabular}{lcc}
\hline Monitoring topic & $\begin{array}{c}\text { Permittees }(\%) \\
(n=248)\end{array}$ & $\begin{array}{c}\text { Agency } \\
\text { employees (\%) } \\
(n=116)\end{array}$ \\
\hline Why to monitor & 14 & 10 \\
Where to monitor & 31 & 22 \\
When to monitor & 35 & 24 \\
Training on specific methods & 47 & 54 \\
Assessing the reliability of methods/protocols & 23 & 56 \\
Monitoring forage utilization & 37 & 37 \\
Plant identification & 52 & 44 \\
Riparian monitoring & 19 & 48 \\
Monitoring soil characteristics and processes & 21 & 49 \\
Wildlife habitat monitoring & 18 & 31 \\
Water quality monitoring & 19 & 24 \\
Analyzing and interpreting monitoring data & 24 & 49 \\
Communicating monitoring results & 14 & 29 \\
Using monitoring as a management guide & 36 & 41 \\
\hline
\end{tabular}

role in mediating conflicts. Often, Extension's educational programs, such as field monitoring workshops, serve to bring differing interests together in a collaborative learning environment that fosters respectful interactions and joint learning. These experiences open lines of communication and help build trust.

Focus groups also characterized Extension agents as objective, unbiased, professional, and of high integrity, qualities that have enabled Extension to earn the trust of diverse interests. This trust in turn allows Extension staff to mediate conflicts effectively and facilitate constructive dialog among potentially conflicting groups and individuals. However, despite the value placed on Extension's objectivity, some permittees fault Extension for failing to "stand up for the truth" and advocate for them, whereas some agency staff perceive Extension agents as being too closely identified with their rancher clientele, compromising objectivity and credibility.

\section{Information Needs and Preferences}

A majority of survey respondents in both groups were interested in increasing their knowledge of rangeland monitoring. Sixty-six percent of ranchers and $88 \%$ of agency employees reported that they had looked for information on rangeland monitoring at some point (Table 6). Permittees who had looked for monitoring information most often consulted other ranchers $(57 \%)$, Cooperative Extension workshops $(50 \%)$, Extension publications $(40 \%)$, and NRCS range conservationists (40\%). Cooperative Extension agents were consulted by 39\% of permittees looking for monitoring information. Agency employees most often sought information from Cooperative Extension monitoring publications (64\%) and Extension monitoring workshops, university professors, and the Society for Range Management (63\% each).

Of those who responded to the question, permittees reported that they prefer to receive information through on-site help from Extension agents or other professionals $(55 \%)$, workshops or classes $(50 \%)$, and demonstrations (41\%; Table 7$)$. Among information sources that don't require in-person delivery, pamphlets $(39 \%)$, videos $(31 \%)$, and newsletters $(27 \%)$ were preferred by permittees. Among agency employees, 74\% preferred workshops or classes, $51 \%$ on-site help from Extension, and $50 \%$ demonstrations. Forty-one percent of agency staff indicated that a Web site would be useful to them, in contrast to only $15 \%$ of permittees.

Permittees expressed greatest need for information on plant identification $(52 \%)$, training on specific monitoring methods $(47 \%)$, utilization monitoring $(37 \%)$, and use of monitoring as a management guide (36\%; Table 8 ). Agency employees were most interested in information about assessing the reliability of methods or protocols $(56 \%)$, training on specific methods $(54 \%)$, analyzing and interpreting monitoring data (49\%), and monitoring soil characteristics and processes $(49 \%)$.

Permittees and agency employees held different views of the reliability of various information sources on rangeland management. Permittees reported that the most reliable sources of information were other ranchers $(82 \%)$, the Cattlegrowers Association (77\%), Cooperative Extension agents $(73 \%)$, and NRCS range conservationists $(66 \%)$. Agency employees found Forest Service range conservationists most reliable $(90 \%),{ }^{1}$ followed by research in a scientific journal $(89 \%)$, university professors $(81 \%)$, and the Society for Range Management $(77 \%)$. Seventy-five percent of agency employees rated Cooperative Extension agents somewhat or very reliable sources of information. Permittees and agency employees shared the perception that environmental organizations were the least reliable sources of information. Seventy percent of permittees found The Nature Conservancy (TNC) to be unreliable, whereas $50 \%$ of agency staff believed TNC to be a credible information source.

\section{DISCUSSION}

\section{Extension Effectiveness and Information Needs}

The survey responses indicate that Arizona Cooperative Extension is reaching a large proportion of its target audience, particularly among agency employees. Most respondents who received Extension monitoring services reported that it increased their knowledge, and a majority also responded that Extension information influenced their monitoring or other management activities. Compared with other states in which adoption of rangeland monitoring has been assessed (Richards and George 1996; Coppock and Birkenfeld 1999), the survey indicates that a high proportion of Arizona permittees conduct some type of formal vegetation monitoring. Because the nonresponse follow-up survey indicated that respondents were more likely to implement monitoring than nonrespondents, our results might overestimate the proportion of permittees that monitor. Even when this potential bias is taken into account, however, a greater proportion of Arizona permittees monitor than was found in previous studies.

We also found that permittees with Extension contact were more likely to monitor and use more types of monitoring than those without Extension exposure. Although we cannot infer from this that Extension involvement led permittees to implement monitoring, there is a strong association between Extension contact and permittees' use of monitoring and other beneficial management practices. Further study is needed to

\footnotetext{
${ }^{1}$ This high rating of USFS range conservationists probably reflects the disproportionate number of USFS employees in the agency sample.
} 
determine causal relationships and the strength of Extension's influence on permittee behavior. It could be that permittees who use progressive management approaches, including monitoring, are also more likely to seek out information and assistance from Cooperative Extension and that this is part of an overall pattern of proactive management behavior.

Cooperative Extension can do little to directly affect the major obstacles to agency monitoring-lack of resources and preemption by other agency priorities. Permittees, on the other hand, are largely hindered by lack of knowledge about and confidence in monitoring methods, as well as resource constraints. Cooperative Extension can address these factors by continuing its rangeland monitoring program, with increasing emphasis on follow-up support for permittees who attend initial training workshops. Because permittees consider their peers their most reliable information source and because their greatest information needs are for basic and follow-up training in monitoring methods, fostering rancher-to-rancher monitoring support networks could help provide needed reinforcement for Extension training workshops, thus leveraging the effect of Extension's educational services. Continued permittee capacity-building in rangeland monitoring might eventually help relieve some of the burden on agency employees. As reported elsewhere (Fernandez-Gimenez and Jorstad McClaran 2003), both surveyed agency employees and permittees strongly supported permittee monitoring of public land grazing allotments.

Another continuing challenge to monitoring implementation is the perception by one-third of both populations that monitoring does not help them make management decisions. This response is somewhat contradicted by the large majority of both groups that said they monitor in part to make decisions about the timing of grazing and stocking rates. Still, the survey data suggest that more must be done to plan and conduct monitoring in ways that ensure its utility for decision-making. (Thirty-six percent of permittees and $41 \%$ of agency employees requested information on using monitoring as a management guide.) Articulating clear management and monitoring objectives is a good starting point (Elzinga et al. 1998). The lack of congruity between the timescale for obtaining meaningful trend data and the timeframe required for short-term decisionmaking also limits the application of monitoring to management decisions. Robust and meaningful short-term indicators of trends must be developed and applied in concert with longterm condition and trend monitoring. Utilization measurements have traditionally been used as a short-term decision-making tool but are highly problematic because of the inherent, and often unsupported, assumptions about the relationships between utilization and range condition and production and the improper application of utilization methods (Sharp et al. 1994; Oregon State University Agricultural Experiment Station 1998). To meet these needs, Reed et al. (1999) and Rittenhouse and Roath (2002) developed the Grazing Response Index, which incorporates several easily observable short-term indicators, making it more robust than utilization alone.

Like permittees, agency employees rated their immediate peers as the most reliable source of information, with scientific sources (journal articles and university professors) ranking 2nd. They strongly prefer to receive monitoring information through direct face-to-face contact with Extension personnel and rely greatly on Extension for monitoring information. They are most interested in learning new methods and improving their ability to assess the validity of monitoring methods and to analyze and interpret data. These findings indicate that agency employees attend to new scientific developments in monitoring and want to increase their capacity to evaluate and apply both new and established monitoring approaches. These results point to the continued need for close communication and cooperation between university-based researchers and Extension specialists, county agents, and natural resource agency staff on monitoring-related advances in rangeland science.

\section{Monitoring Can Improve Permittee-Agency Relationships}

In many instances, permittees and agency employees perceive that monitoring improves permittee-agency relationships. Agency employees were more likely to perceive this benefit than permittees; however, most permittees felt that monitoring did no harm to their relationship with the agencies, and $45 \%$ reported that it improved their relationship with the BLM. We speculate that improved agency-permittee relationships make positive on-the-ground management changes more likely. Improved agency-permittee relationships presumably could also enhance the security of lease tenure for permittees. Finally, if the involvement of permittees in monitoring reduces agencypermittee conflict, joint monitoring with permittees and other interested parties might conceivably reduce the number of legal challenges brought by concerned citizens' groups seeking to influence management of public land grazing allotments. We emphasize that these potential effects of joint monitoring remain highly speculative until further tested. However, if substantiated, they could have important implications for the allocation of resources to monitoring and, particularly, permittee involvement in monitoring. Additional studies are needed to further investigate the implications of improving communication and working relationships between permittees and agency employees and to identify factors that promote and obstruct productive permittee-agency interactions.

Although the interpersonal and bureaucratic relationships between permittees and agency employees are crucial aspects of management, little if any study has been devoted to understanding the ways that these relationships influence management outcomes or how they can be improved. In a case study of ranchers near Big Bend, Texas, Weeks and Packard (1997) concluded that social relationships between agency employees and resource users were 1 of 4 key factors affecting the acceptance of scientific information (and science-based management prescriptions) by resource users. Similarly, Siepen and Westrup (2002) contend that effective communication between managers and stakeholders (including resource users) is crucial to successful vegetation management and argue for integrative and participatory approaches to science and management. These studies, and our findings, point to the potential contributions social science can make to rangeland management by investigating how social relations among scientists, managers, and resource users affect the social, economic, and environmental outcomes of management.

\section{Rangeland Monitoring as a Social Process and the Role of Cooperative Extension}

Rangeland monitoring affects social relationships in various ways. For example, permittee monitoring often improves 
permittee-agency relationships, and participation by multiple interest groups in monitoring workshops improves communication and understanding among potentially adversarial parties. Thus, rangeland monitoring must be understood as a social process as well as a technical activity. Our findings also show that Arizona Cooperative Extension agents play an important role in mediating and facilitating the social process of monitoring. Extension agents in the rangeland monitoring program organize workshops and tours that bring ranchers, agency employees, and other interested individuals together; promote permittee monitoring and encourage permittees and agency staff to monitor together; and occasionally provide technical expertise in conflicts over interpreting monitoring results or applying them to management.

The focus groups and written comments on the survey pointed to the importance of the Extension agent's role as informal facilitator and mediator but also brought to light the tensions that agents experience in this position. The most obvious discord lies in the competing pressures to be neutral and objective, on one hand, and to advocate for the producer, the agency, or the resource on the other. A more subtle tension exists between the agent's role as technical expert and educator and the role as facilitator and mediator. Often it is precisely an agent's expertise and status as the voice of objectivity and science that situate them in the middle of opposing interests. Furthermore, our evaluation indicates that Extension is often successful in helping to bring about mutually satisfying resolution to conflicts over monitoring data and related management issues.

These revelations raise important issues about the nature of Extension work in rangeland monitoring. Are agents mediators and facilitators or are they educators and technical experts? Can they act as both? What are the implications of this shift in roles from educator to mediator/facilitator? The reality is that in their role as technical experts, Extension agents often perform mediation and facilitation functions informally, in some cases by virtue of their expertise. However, Extension agents are also charged with serving their clientele, traditionally agricultural producers, and representing the interests of their clients. In contrast, a neutral facilitator or mediator must remain entirely impartial and unbiased in order to be effective. Because of these conflicting demands, Extension agents are not well-suited to serve as professional mediators and facilitators. Nonetheless, Extension agents, like other natural resource professionals, need basic training and skills in interpersonal communication and conflict resolution. Instead of perfect objectivity (an impossible goal in any case), agents should strive for integrity and transparency in their relationships with divergent client groups, rely on their scientific training and technical expertise to inform their views and assessments, and explicitly identify the values and attitudes that influence their recommendations.

\section{CONCLUSIONS}

We suggest that rangeland monitoring should be understood as a social process with important social outcomes, as well as a technical activity that produces data. Our evaluation indicates that Cooperative Extension agents play a key role in both the social and technical aspects of rangeland monitoring in Arizona. Social science can make a practical contribution to rangeland management by bringing to light the ways that social relationships influence management actions and outcomes and by identifying the factors that enhance or diminish these relationships.

\section{ACKNOWLEDGMENTS}

We appreciate the support and ideas of natural resource extension agents throughout Arizona, especially Robin Grumbles, Chris Jones, Kim McReynolds, Susan Pater, Jeff Schalau, and Jim Sprinkle. We thank Sandra Jimenez and Julie Conley for assistance in focus group notetaking and transcription; Rachel Meade for compiling the sampling frames; Mitch McClaran, Mac Donaldson, Sue Chilton, Mary Miller, John Hays, Jr, Kristen Egen, Mark Hocken, and Fred Denecke for reviewing survey drafts; and Alexander Conley, Mary Hershdorfer, and John Hays, Jr, for helping with survey mailings. The assistance and cooperation of the Arizona offices of the USFS, BLM, and NRCS and the Arizona State Lands Department are gratefully acknowledged, as is the cooperation of the Gila County Cattlegrowers and many other Arizona ranchers. Larry Rittenhouse, Mel George, and 2 anonymous reviewers provided helpful comments that improved the manuscript.

\section{LITERATURE CITED}

Brunson, M. W., AND B. S. SteEL. 1996. Sources of variation in attitudes and beliefs about federal rangeland management. Journal of Range Management 49:69-75.

Coppock, L. D., AND A. H. BiRKenfeld. 1999. Use of livestock and range management practices in Utah. Journal of Range Management 52:7-18.

Dillman, D. A. 2000. Mail and Internet surveys, the Tailored Design Method, 2nd ed. New York, NY: Wiley and Sons Inc. 464 p.

Elzinga, C. L., D. W. Salzer, and J. W. Willoughby. 1998. Measuring and monitoring plant populations. Denver, CO: Bureau of Land Management. $477 \mathrm{p}$.

Fernandez-Gimenez, M., and S. Jorstad McClaran. 2003. Rangeland monitoring program evaluation report. Tucson, AZ: University of Arizona Cooperative Extension. $21 \mathrm{p}$.

Liffman, R. H., L. Huntsinger, and L. C. Forero. 2000. To ranch or not to ranch: home on the urban range? Journal of Range Management 53:362-370.

NoRUSIS, M. J. 1990. SPSS base system user's guide. Chicago, IL: SPSS Inc. 520 p.

Oregon State University Agricultural Experiment Station. 1998. Stubble height and utilization measurements: Uses and misuses. Corvallis, OR: Oregon State University Agricultural Experiment Bulletin 682. 72 p.

Peterson, E. 2000. Permittee monitoring on Wyoming's Bridger-Teton National Forest. Available at: http://www.uwyo.edu/ces/County_Info/SUBLETTE/. Accessed 23 July 2003.

QSR. 2000. QSR N*VIV0. Melbourne, Australia: QSR International Pty. Ltd.

ReEd, F., R. Roath, and D. BRadford. 1999. The grazing response index: a simple and effective method to evaluate grazing impacts. Rangelands 21:3-6.

RichaRdS, R. T., AND M. R. GEORGE. 1996. Evaluating changes in range management practices through extension education. Journal of Range Management 49:76-80.

Richards, R. T., AND L. Huntsinger. 1994. Variation in BLM employee attitudes toward environmental conditions on rangelands. Journal of Range Management 47:365-368.

RitTenhouse, L. R., AND R. RoATH. 2002. Monitoring grazing practices and stocking rates for sustainability. Acta Prataculturae Sinica 11(1):91-99.

Sharp, L., K. Sanders, and N. Rimbey. 1994. Management decisions based on utilization-is it really management? Rangelands 16(1):38-40.

Siepen, G. L., and J. Westrup. 2002. Communicating vegetation management science to land managers and other stakeholders. Rangeland Journal 24(1):170-181.

SPSS, INc. 1999. SPSS for Windows 10.0.5. Chicago, IL: SPSS, Inc.

Stewart, D. W., and P. N. Shamdasani. 1998. Focus group research, exploration and discovery. In: L. Bickman and D. J. Rog [eds.]. Handbook of applied social research methods. Thousand Oaks, CA: Sage Publications. p. 505-526.

Strauss, A., And J. Corbin. 1998. Basics of qualitative research. Thousand Oaks, CA: Sage Publications. 312 p.

WeEks, P., AND J. M. Packard. 1997. Acceptance of scientific management by natural resource dependent communities. Conservation Biology 11(1):236-245. 